\title{
Integrative Pharmacotherapy Teaching with Objective Structured Pharmacotherapy Examination
}

\author{
Abraham Simatupang, Mulyadi Djojosaputro, Roma Tobing, \\ Hertina Silaban, Lili Indrawati \\ Department of Pharmacology and Therapy, Faculty of Medicine, \\ Universitas Kristen Indonesia, East Jakarta, Indonesia
}

\begin{abstract}
Writing an appropriate prescription is one of the main competencies of medical doctors. Studies reveal that medication error is still a significant issue in health service, and many efforts have been done to minimise this through trainings. Integrative pharmacotherapy is a module delivered for medical students in clinical clerkship, which is adopted and developed from the World Health Organization Guide to Good Prescribing. The aim of the study was to examine the effect of the module on pre-test and post-test scores which consists of 17 clinical cases. The study was done in the Faculty of Medicine, Universitas Kristen Indonesia, East Jakarta from July to November 2018. Eighty one subjects were randomly selected from the data of 100 students who were screened from 200 students based on the exclusion criteria. There was an increase of post-test score which was statistically significant compared to pre-test score, from $42.07 \pm 12.45$ to $58.47 \pm 8.54$ ( $\mathrm{p}=0.000, \mathrm{CI}-19.36 ;-13.45)$. There were $69(>85 \%)$ students having grade $\mathrm{D}$ and $\mathrm{E}$ in pre-test, but the number decreased to $18(22,2 \%)$ out of 81 subjects in post-test. Both grade $\mathrm{C}$ and $\mathrm{B}$ students increased from $13.5 \%$ to $70.4 \%$ and $1 \%$ to $7 \%$, respectively. Most of the students were first entries into clinical clerkship, thus, their pre-test scores were very low since they had not had the clinical experience yet. However, at the end of the clerkship, there was a significant increase on their knowledge on pharmacotherapy and prescription for particular diseases. An outcome study to measure the retention and to examine their success on the final competency examination should be done.
\end{abstract}

Keywords: Medical education, OSCE, pharmacotherapy, prescribing

\section{Pembelajaran Farmakoterapi Integratif dengan Objective Structured Pharmacotherapy Examination}

\begin{abstract}
Abstrak
Menulis resep yang benar merupakan salah satu kompetensi dokter. Penelitian menunjukkan kesalahan medikasi masih menjadi masalah besar di pelayanan kesehatan dan banyak upaya sudah dilakukan untuk mengurangi hal tersebut melalui pelatihan. Farmakoterapi integratif adalah sebuah modul yang diberikan kepada mahasiswa kedokteran saat kepaniteraan klinis. Modul ini merupakan hasil adopsi dan dikembangkan dari World Health Organization Guide to Good Prescribing. Tujuan studi ini adalah untuk melihat efek nilai pra-uji dan pasca-uji dengan 17 kasus klinis. Studi dilaksanakan di Fakultas Kedokteran Universitas Kristen Indonesia, Jakarta Timur pada Juli-November 2018. Delapan puluh satu subjek secara acak dipilih dari data 200 mahasiswa berdasarkan kriteria eksklusi. Terdapat peningkatan

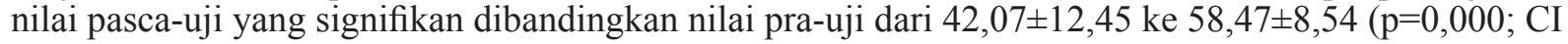
$-19,36 ;-13,45)$. Terdapat $69(>85 \%)$ mahasiswa yang memiliki nilai D dan E pada pra-uji, namun angka tersebut turun pada pasca-uji menjadi 18 orang $(22,2 \%)$ dari jumlah total 81 mahasiswa. Mahasiswa dengan nilai $\mathrm{C}$ meningkat dari $13,5 \%$ menjadi $70,4 \%$, dan mahasiswa dengan nilai $\mathrm{B}$ dari $1 \%$ menjadi 7\%. Mayoritas mahasiswa pada penelitian ini baru pertama kali mengikuti kepaniteraan klinik sehingga nilai pra-uji yang diperoleh sangat rendah karena belum memiliki pengalaman klinis. Namun, di akhir kepaniteraan, terdapat peningkatan pengetahuan dan penulisan resep terhadap beberapa jenis penyakit yang signifikan. Perlu dilakukan studi jangka panjang untuk mengukur retensi dan keberhasilan mereka di ujian akhir kompetensi.
\end{abstract}

Kata kunci: Farmakoterapi, OSCE, pendidikan kedokteran, penulisan resep

Correspondence: Dr.med., dr. Abraham Simatupang, M.Kes., Department of Pharmacology and Therapy, Faculty of Medicine, Universitas Kristen Indonesia. East Jakarta, Special Capital Region of Jakarta 13630, Indonesia, email: abraham.simatupang@uki.ac.id

Submitted: 16 ${ }^{\text {th }}$ April 2019, Accepted: 19 ${ }^{\text {th }}$ December 2019, Published: 31 ${ }^{\text {st }}$ March 2020 


\section{Introduction}

Pharmacotherapy is one of the many subjects which medical students should learn during their clinical clerkship. Pharmacotherapy is a subject that is close to clinical pharmacology where students start to integrate and "digest" the basic pharmacology (pharmacokinetics and pharmacodynamics) which they learnt in the pre-clinical semesters into a clinical setting. The usual measurement of output on learning of pharmacotherapy is writing a prescription, but a prescription is not merely a list of medicine with some regulations and precautions of how medicine should be taken by the patients but also how and why the prescribers choose those particular medicines towards the benefit of their patients. Thus, writing a prescription is actually a decision making process in which every prescriber should consider many aspects apart from the diagnosis. Therefore, it is revealed in many studies that inappropriate prescribing still becomes one of the problems existing in many health services. ${ }^{1-3}$ There are also a lot of trainings given to medical doctors or nurses for reducing this problem. ${ }^{4}$ Faced with this problem, many trainings of writing prescription, through many approaches, are done for medical students, especially during their clinical clerkship, but the results are various. ${ }^{2,4,5}$

Recently, Department of Pharmacology and Therapy, Faculty of Medicine, Universitas Kristen Indonesia (FM UKI) has developed a module of integrative pharmacotherapy. The students learn pharmacotherapy through simulated-cases and real cases taken from the hospital, and they learn how to choose the medicine and prescription properly in accordance to the cases. The students also have to appraise critically prescriptions that are given from the hospital. The core concept of the module is adopted and developed from the World Health Organization (WHO)
Guide to Good Prescribing. Vollebregt, ${ }^{6}$ Sandilands et al., ${ }^{4}$ de Vries and Reade, et al. ${ }^{7}$ have reviewed and constructed, at least in the Netherlands, the curriculum and method of teaching and learning of pharmacotherapy. Therefore, a rubric was developed which was adopted from Objective Structured Clinical Examination (OSCE) called Objective Structure Pharmacotherapy Examination (OSPE). The aim of the study is to compare the grade of the students who have taken pre- and posttest during their integrative pharmacotherapy clerkship.

\section{Methods}

Subjects of the study were medical students of FM UKI, East Jakarta, who took their clinical clerkship of Integrative Clinical Pharmacotherapy at $5^{\text {th }}-6^{\text {th }}$ year. This was a pre- and post examination study. At the beginning of clerkship, the students took a pretest, and they continued the clerkship which lasted for 6 weeks afterwards. During the first and second week, they learnt the concept of prescription writing, at the third to sixth week students were rotated to the Department of Internal Medicine, Department. of Pediatrics, Department of Skin and Venereaology Diseases, Department of Opthalmology and Department of Ear, Nose and Throat (ENT). In these departments, students directly learn and critically appraise the prescribed medicines for in-patient and out-patient. During the clerkship students also wrote short-articles on certain drugs that are important and will be prescribed frequently in the practice, such as anti hypertensive drugs, drugs for tuberculosis, etc. At the end of the rotation, they have to take OSPE. Students took pretest and post-test scores at the first and sixth week respectively. From first week to fifth week, students learn many aspects as written in the syllabus shown in Table 1.

Subjects who were included in this study 
Table 1 Timetable and Contents of the Integrative Pharmacotherapy Module

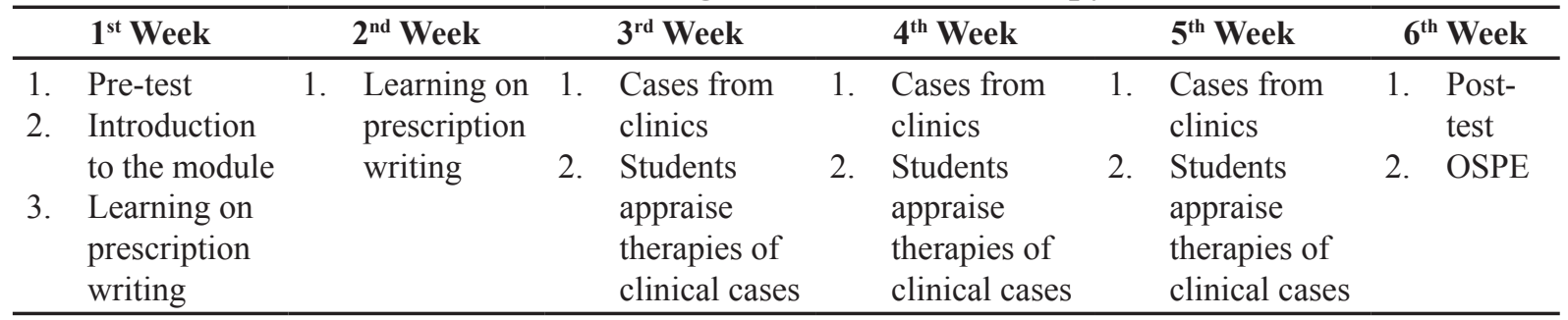

were randomly taken from the whole students data-set. They had taken both pre-test and post-test. Two hundred students who had had taken the module were registered in student's data-set, and they were primarily selected by excluding students who were repeater. From this procedure, 100 students were found to be eligible. Number of students taken as sample were calculated using Slovin formula, which came to $80 .{ }^{8}$ Hence, a total of 81 students were randomly selected from 100 students as subjects in this study (Figure 1). The pre-test and post-test consisted of 17 clinical cases; the cases were presented in Google Forms. The students clicked on the answers provided or wrote a prescription as instructed.

Seventeen clinical cases studied by the students on tests were clinical cases that should be mastered by every Indonesian general practitioner according to Standar Kompetensi Dokter Indonesia (SKDI) 2012 (Indonesian Medical Doctor's Standard of Competence 2012), ${ }^{9}$ such as uncomplicated hypertension, type-2 diabetes mellitus, certain infectious diseases, anaemia, etc. These materials are also tested on Uji Kompetensi Mahasiswa Program Profesi Dokter (UKMPPD) (Competency Test of Doctor Profession Program) in the form of Computer Based Testing and OSCE.

Student t-test for paired data was used to calculate whether there was a difference between pre-test and post-test values between female and male students and the whole students. Statistical analysis was performed using the SPSS Version 22 and results were considered significantly different at 5\% $(\mathrm{p}<$ $0.05)$. This study was conducted from July to November 2018 and had been approved by

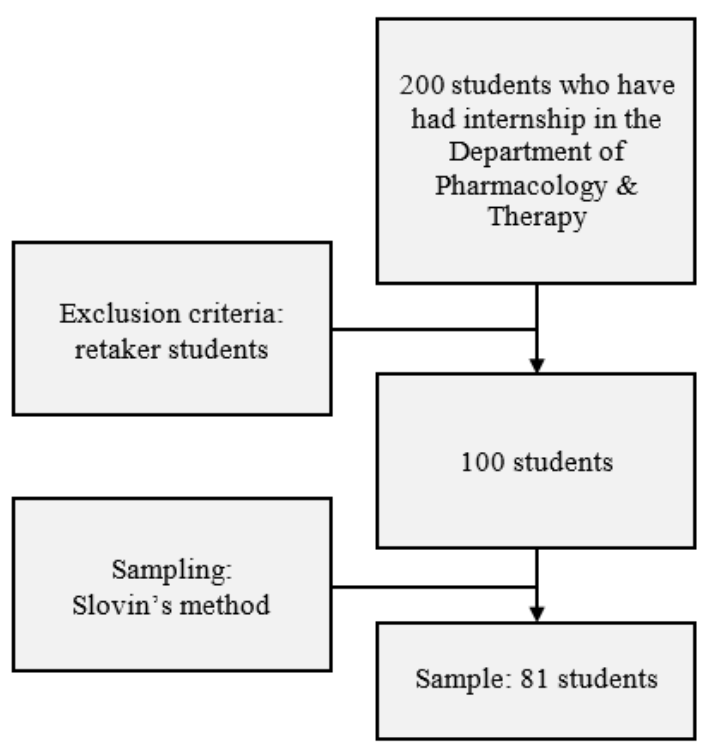

Figure 1 Subjects Recruitment 
Table 2 Rubric of Objective Structured Pharmacotherapy Examination (OSPE)

\begin{tabular}{|c|c|c|c|c|c|c|}
\hline \multirow{2}{*}{$\begin{array}{l}\text { Examination / } \\
\text { Item(s) }\end{array}$} & \multicolumn{4}{|c|}{ Score } & \multirow{2}{*}{ Weight } & \multirow{2}{*}{$\begin{array}{l}\text { Total } \\
\text { Score }\end{array}$} \\
\hline & $\mathbf{0}$ & 1 & 2 & 3 & & \\
\hline $\begin{array}{l}\text { Aim/goal of } \\
\text { therapy }\end{array}$ & $\begin{array}{l}\text { Does not set } \\
\text { therapeutic goals }\end{array}$ & $\begin{array}{l}\text { Provides an } \\
\text { incomplete } \\
\text { explanation of } \\
\text { the goals of } \\
\text { therapy }\end{array}$ & $\begin{array}{l}\text { Provides a } \\
\text { quite complete } \\
\text { explanation of the } \\
\text { therapeutic goals }\end{array}$ & $\begin{array}{l}\text { Provides a } \\
\text { comprehensive } \\
\text { explanation of } \\
\text { therapeutic goals }\end{array}$ & 2 & 6 \\
\hline Prescription & $\begin{array}{l}\text { Does not submit a } \\
\text { prescription }\end{array}$ & $\begin{array}{l}\text { Submit a } \\
\text { prescription. } \\
\text { However, } \\
\text { there is no } \\
\text { information } \\
\text { other than just } \\
\text { mentioning } \\
\text { the name of } \\
\text { the drug, the } \\
\text { amount and how } \\
\text { to use it }\end{array}$ & $\begin{array}{l}\text { Submit a } \\
\text { prescription. } \\
\text { But list only } 3 \\
\text { of the following } \\
\text { information: } \\
\text { 1. Name and } \\
\text { address of } \\
\text { doctor's practice } \\
\text { 2. Name and } \\
\text { address of the } \\
\text { patient } \\
\text { 3. Drug name, } \\
\text { amount and } \\
\text { dosage } \\
\text { 4. How to use }\end{array}$ & $\begin{array}{l}\text { Submit a } \\
\text { prescription } \\
\text { and list all four } \\
\text { elements below: } \\
\text { 1. Name and } \\
\text { address of } \\
\text { doctor's practice } \\
\text { 2. Name and } \\
\text { address of the } \\
\text { patient } \\
\text { 3. Drug name, } \\
\text { amount and } \\
\text { dosage } \\
\text { 4. How to use }\end{array}$ & 3 & 9 \\
\hline $\begin{array}{l}\text { Indication(s) and } \\
\text { contraindication(s) }\end{array}$ & $\begin{array}{l}\text { Does not } \\
\text { know at all the } \\
\text { indications and } \\
\text { contraindications } \\
\text { of the given drug }\end{array}$ & $\begin{array}{l}\text { Knows only } 1 \\
\text { indication and } \\
\text { contraindication } \\
\text { of the given } \\
\text { drug(s) }\end{array}$ & $\begin{array}{l}\text { Knows only } 2 \text { the } \\
\text { indication(s) and } \\
\text { contraindication(s) } \\
\text { of the given } \\
\text { drug(s) }\end{array}$ & $\begin{array}{l}\text { Knows all } \\
\text { indications and } \\
\text { contraindications } \\
\text { of the given drugs }\end{array}$ & 2 & 6 \\
\hline $\begin{array}{l}\text { Adverse drug } \\
\text { reaction(s) }\end{array}$ & $\begin{array}{l}\text { Does not know } \\
\text { any of adverse } \\
\text { effects of the } \\
\text { given drug(s) }\end{array}$ & $\begin{array}{l}\text { Knows only one } \\
\text { adverse effect } \\
\text { of the given } \\
\text { drug(s) }\end{array}$ & $\begin{array}{l}\text { Knows two } \\
\text { adverse effect(s) } \\
\text { of the given } \\
\text { drug(s) }\end{array}$ & $\begin{array}{l}\text { Knows more } \\
\text { than two adverse } \\
\text { effects of the } \\
\text { given drug(s) }\end{array}$ & 2 & 6 \\
\hline Drug interaction(s) & $\begin{array}{l}\text { Does not know } \\
\text { the possibility of } \\
\text { drug interaction } \\
\text { of the given drugs }\end{array}$ & $\begin{array}{l}\text { Knows only one } \\
\text { drug interaction } \\
\text { of the given } \\
\text { drugs }\end{array}$ & $\begin{array}{l}\text { Knows two drug } \\
\text { interactions of the } \\
\text { given drugs }\end{array}$ & $\begin{array}{l}\text { Knows more } \\
\text { than two drug } \\
\text { interactions of the } \\
\text { given drugs }\end{array}$ & 2 & 6 \\
\hline
\end{tabular}

the Ethics Review Committee of FM UKI no. 11/Etik Penelitian/FKUKI/2018.

\section{Results}

Table 3 shows the mean of the students as divided by gender as well as the total students. The scores between pre- and post-test are significant, whereas scores between gender is not significant. Figure 2 and 3 shows the box- plot of both pre- and post test between women and men. Number of students was calculated based on their grade classification as depicted in Table 4. It appears that there is increasing number of students who originally got grade $\mathrm{D}$ and $\mathrm{E}$ which turned into $\mathrm{C}$ and $\mathrm{B}$.

\section{Discussion}

As mentioned in many studies, inappropriate 
Table 3 Students' Pre- and Post-test Scores

\begin{tabular}{lccc}
\hline \multirow{2}{*}{ Gender $(\mathbf{N})$} & Pre-test Score & Post-test Score & \\
\cline { 2 - 3 } & $($ Mean \pm SD) & $($ Mean \pm SD) & p \\
\hline Female (60) & $42.06 \pm 11.84$ & $58.18 \pm 7.91$ & Not significant \\
Male (21) & $42.1 \pm 14.36$ & $59.31 \pm 10.31$ & \\
Total (81) & $42.07 \pm 12.45$ & $58.47 \pm 8.54$ & $0.000(\mathrm{CI}-19.36 ;-13.45)$ \\
\hline
\end{tabular}

prescription is still one of the main issues found in health services either in developing countries or developed countries. ${ }^{8,10}$ Most of the findings from these studies show an overuse of antibiotics and polypharmacy. ${ }^{8,9}$ Unnecessary prescription includes giving medicaments that are actually not needed, such as lipid-lowering agents or acetylcholine esterase inhibitor for advanced dementia patients, is also profound. ${ }^{1}$ In overcoming this problem, numerous trainings for prescribers and medical students have been done. ${ }^{11,12}$ Many studies on prescription writing training for medical students, for instance studies by de Vries et al., are also available. ${ }^{5,13-15}$ Their core concept of method is WHO Guide to Good Prescribing, which is used and developed in medical faculty in both developing countries and developed countries. ${ }^{16-19}$

In this study, it is shown that a significant increase of knowledge in pharmacotherapy was found as depicted through their grade scores. Before the intervention, more than $85 \%$

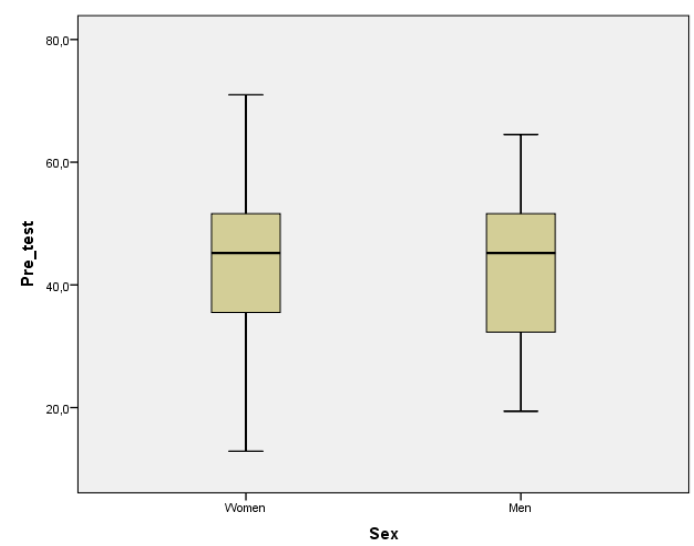

Figure 2 Box-plot of Mean Scores of Pre-test by Gender subjects got D or E (less satisfactory and fail). Despite the fact that as many as $22.2 \%$ subjects still got D or E after intervention, there are is an increasing number of students who get C (satisfactory) and B (good) from $13.5 \%$ to $70.4 \%$ and $1 \%$ to $7 \%$, respectively. However, no students with grade A (excellent) found after the intervention.

One possible reason about high percentage (more than $85 \%$ ) of incoming students' poor results of pre-test grade is that the students are generally the very first students to enter clinical clerkship, and hence they have not yet entered the clinical department such as internal medicine, pediatrics, ophthalmology, etc. Other influencing factors are, only 4-week period is scheduled for basic pharmacology lecture (e.g. introduction to pharmacology, pharmacokinetics, pharmacodynamic, etc.), and specific subjects of pharmacology are given separately in the blocks or modules. However, it is shown that some knowledge on pharmacotherapy for particular diseases

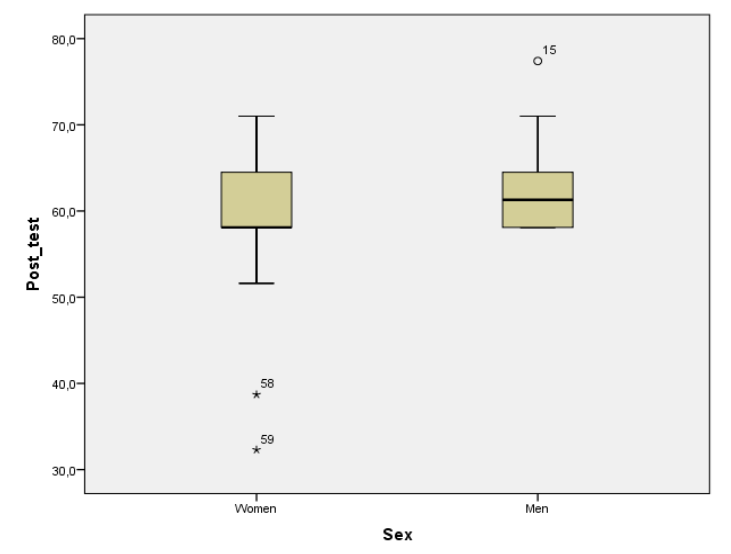

Figure 3 Box-plot of Mean Scores of Post-test by Gender 
Table 4 Number and Percentage of Students Based on Grades

\begin{tabular}{|c|c|c|c|c|c|}
\hline \multirow{2}{*}{$\begin{array}{l}\text { Letter } \\
\text { Grade }\end{array}$} & \multirow{2}{*}{ Predicate } & \multirow{2}{*}{$\begin{array}{l}\text { Range of } \\
\text { Numerical } \\
\text { Grade }\end{array}$} & \multicolumn{2}{|c|}{ Number of Subjects (\%) } & \multirow{2}{*}{$\begin{array}{c}\text { Percentage } \\
\text { of Increase or Decrease } \\
\text { of Students' Achievement }\end{array}$} \\
\hline & & & Pre-test & Post-test & \\
\hline A & Excellent & $80.00-100.00$ & $0(0)$ & $0(0)$ & $0 \%$ \\
\hline $\mathrm{B}$ & Good & $68.00-79.99$ & $1(1)$ & $6(7)$ & $500 \%$ \\
\hline $\mathrm{C}$ & Satisfactory & $56.00-67.99$ & $11(13.5)$ & $57(70.4)$ & $418 \%$ \\
\hline $\mathrm{D}$ & Less satisfactory & $45.00-55.99$ & $27(33.3)$ & $14(17.2)$ & $\downarrow 48 \%$ \\
\hline \multirow[t]{2}{*}{$\mathrm{E}$} & Fail & $0.00-44.99$ & $42(51.8)$ & $4(5)$ & $\downarrow 950 \%$ \\
\hline & Total & & $81(100)$ & $81(100)$ & \\
\hline
\end{tabular}

significantly increased during their clerkship in our department. As stated also in the goal of the module, students were firstly introduced to the decision making process according to the WHO Guide to Good Prescribing, namely 6-steps of rational therapy: step 1: define the patient's problem; step 2: specify the therapeutic objective; step 3: verify whether your p-treatment is suitable for this patient; step 4: start the treatment; step 5: give information, instructions and warnings; and last, step 6: monitor (stop) the treatment. This module emphasizes students to have better understanding in the process of selecting medicines according to the context of patients they are facing.

Limitation of this study is that it does not employ a control group. Nevertheless, we had tried setting students set as control, i.e. students who had not taken this module yet. However, it is difficult to get their post-test accurately since they were already in another department's clerkship.

\section{Conclusion}

This integrative pharmacotherapy approach, far as we know, is one of its kind, to put the pharmacology in clinical context in clerkship, especially focusing on the decision making process in pharmacotherapy of which medical students should learn as earlier as possible. With regards to the outcome, we have not conducted a correlation study between the pharmacotherapy learning of this model and student's Objective Structure Pharmacotherapy Examination (OSPE) graduation rate. It is also necessary to examine the success of students in joining Uji Kompetensi Mahasiswa Program Profesi Dokter (UKMPPD)/Competency Test of Medical Doctor Profession Program with Objective Structured Clinical Examination (OSCE) model, particularly by looking at examination's result of prescription writing.

\section{Funding}

The study was funded by Faculty of Medicine of Universitas Kristen Indonesia's research funding.

\section{Conflict of Interest}

The authors declared no potential conflicts of interest with respect to the research, authorship, and/or publication of this article.

\section{References}

1. Naples JG, Hanlon JT, Schmader KE, Semla TP. Recent literature on medication errors and adverse drug events in older adults. J Am Geriatr Soc. 2016;64(2):4018. doi: 10.1111/jgs. 13922

2. Bos JM, van den Bemt PMLA, de Smet PAGM De, Kramers C. The effect of 
prescriber education on medication related patient harm in the hospital: A systematic review. Br J Clin Pharmacol. 2017;83(5): 953-61. doi: 10.1111/bcp.13200

3. Truter A, Schellack N, Meyer JC. Identifying medication errors in the neonatal intensive care unit and paediatric wards using a medication error checklist at a tertiary academic hospital in Gauteng, South Africa. S Afr J Child Heal. 2017;11 (1):5-10. doi: 10.7196/SAJCH.2017.v11 i1.1101

4. Sandilands EA, Reid K, Shaw L, Bateman DN, Webb DJ, Dhaun N, et al. Impact of a focussed teaching programme on practical prescribing skills among final year medical students. Br J Clin Pharmacol. 2010;71(1):29-33. doi: 10.11 11/j.1365-2125.2010.03808.x

5. Celebi N, Kirchhoff K, LammerdingKöppel M, Riessen R, Weyrich P. Medical clerkships do not reduce common prescription errors among medical students. Naunyn Schmiedebergs Arch Pharmacol. 2010;382(2):171-6. doi: 10.1007/s00210 -010-0530-9

6. Vollebregt JA. From learning objectives to students competence: Transformation into a pharmacotherapy context-learning programme ( $\mathrm{PhD}$ thesis). Amsterdam: Vrije Universiteit; 2004.

7. de Vries TPGM, Henning RH, Hogerzeil HV, Fresle DA, et al. Guide to good prescribing: A practical manual. Geneva: WHO Action Programme on Essential Drugs; 1994.

8. Hidayat A. Cara hitung rumus Slovin besar sampel, 2019. [Accessed on: 25 February 2019]. Available from: https:// www.statistikian.com/2017/12/hitung-ru mus-slovin-sampel.html

9. Konsil Kedokteran Indonesia. Standar kompetensi dokter Indonesia, edisi kedua. Jakarta: Konsil Kedokteran Indonesia; 2012.
10. Tichelaar J, Kan C Van, Unen RJ Van. The effect of different levels of realism of context learning on the prescribing competencies of medical students during the clinical clerkship in internal medicine: An exploratory study. Eur J Clin Pharmacol. 2015;71(2):237-42. doi: 10.1007/s00228 -014-1790-y

11. Shankar P, Upadhyay D, Dubey A, Mishra P. Prescribing patterns among paediatric inpatients in a teaching hospital in western Nepal. Singapore Med J. 2006;47(4):261 -5 .

12. Mahmood A, Elnour AA, Ali AAA, Hassan NAGM, Shehab A, Bhagavathula AS. Evaluation of rational use of medicines (RUM) in four government hospitals in UAE. Saudi Pharm J. 2016;24(2):189-96. doi:10.1016/j.jsps.2015.03.003

13. Hogerzeil HV, Bimo, Ross-Degnan D, Laing RO, Ofori-Adjei D, Santoso B, et al. Field tests for rational drug use in twelve developing countries. Lancet. 1993;342 (8884):1408-10. doi: 10.1016/0140-6736 (93) $92760-\mathrm{q}$

14. Morgan DJ, Okeke IN, Laxminarayan $\mathrm{R}$, Perencevich EN, Weisenberg S. Nonprescription antimicrobial use worldwide: A systematic review. Lancet Infect Dis. 2011;11(9):692-701. doi: 10.1016/S1473 $-3099(11) 70054-8$

15. Santoso B, Suryawati S, Prawaitasari JE. Small group intervention vs formal seminar for improving appropriate drug use. Soc Sci Med. 1996;42(8):1163-8. doi: 10.1016/0277-9536(95)00390-8

16. Barber SL, Huang B, Santoso B, Laing $\mathrm{R}$, Paris $\mathrm{V}, \mathrm{Wu} \mathrm{C}$. The reform of the essential medicines system in China: A comprehensive approach to universal coverage. J Glob Health. 2013;3(1):10303. doi: 10.7189/jogh.03.010303

17. Vollebregt JA, Metz JCM, de Haan M, Richir MC, Hugtenburg JG, de Vries TPGM. Curriculum development in 
pharmacotherapy: Testing the ability of preclinical medical students to learn therapeutic problem solving in a randomized controlled trial. Br J Clin Pharmacol. 2005; 61(3):345-51. doi: 10.1111/j.1365-2125. 2005.02571.x

18. Tichelaar J, Uil den SH, Antonini NF, van Agtmael MA, de Vries TPGM, et al. A 'SMART' way to determine treatment goals in pharmacotherapy education. $\mathrm{Br}$
J Clin Pharmacol. 2016;82(1):280-4. doi: 10.1111/bcp. 12919

19. Brinkman DJ, Tichelaar J, van Agtmael MA, de Vries TPGM, Richir MC. SelfSelf-reported confidence in prescribing skills correlates poorly with assessed competence in fourth-year medical students. 2015;55(7):825-30. doi: 10.100 $2 / \mathrm{jcph} .474$ 